\title{
Disputed expenses at heart of Moncada's Spanish spat
}

A bitter confrontation between Spain's health ministry and noted researcher Salvador Moncada has left the management of the Spanish National Cardiovascular Center (CNIC) in limbo. The bone of contention: $€ 13,352$ that Moncada allegedly spent on travel expenses.

Launched in 1999, the $€ 60$ million CNIC is expected to house 300 researchers once construction is complete. What distinguishes it-and the Spanish National Cancer Center, led by Mariano Barbacid — from other Spanish institutes is its independent management structure, allowing for innovative collaboration, funding and recruitment.

Moncada, head of the Wolfson Institute for Biomedical Research at University College in London, has been the executive consultant of the institute and was expected to become the director after its completion later this year.

But on 26 May, the Spanish Account Court, which monitors the expenses of ministry-based institutions, alleged that Moncada got "undue payments" for three trips he made to Madrid between January and March 2002. The court ruled that Moncada must return the amount and recommended that he "bury" his practices, including frequent inattendance at institute meetings and stays at luxury hotels in Madrid.

Based on the report, the ministry cancelled Moncada's original contract-which allowed him $€ 1,500$ in expenses per day-and faxed him a new version, promising him a salary equal to Barbacid's. On 23 June, after reports of the dispute had appeared in the Spanish media, Moncada sent a letter to Health Minister Elena Salgado, reminding her that his contract allowed for as many trips as necessary. Moncada added that the charge has damaged his "honor and image" and asked the ministry to issue an apology.

Moncada says his troubles began in April 2003 when, shortly before a regional election, the ministry asked him to provide $€ 1.3$ million from the institute's budget to fund a healthy life campaign. "It sounded as a sort of corruption," Moncada says. He did not authorize the payment and the campaign was never launched.

In November 2003, the ministry appointed a general manager at the institute. Moncada says the post represents a maneuver by the ministry to take control over the institute. "I have to ask permission even to get a pen," he says.

The ministry declined to respond to Moncada's allegations. But Santiago CerveraSoto, who held the post until recently, says "Moncada will not ever accept a manager who has not been appointed by himself." Others

note that the post of general manager is probably necessary to resolve the current CNIC deficit, estimated at $€ 7$ million.

Moncada says he will only continue with the institute if the ministry issues an apology and the post of general manager is eliminated. A spokesman for the ministry says that although Salgado would like to keep Moncada involved in the institute, no apology will be forthcom-

ing. Moncada's original fee was "highly above that of Barbacid," the spokesman says.

The dispute perfectly illustrates the bureaucracy and financial problems that plague Spain's research structure, notes Jordi Petriz, a

stem cell researcher at the Barcelona-based Institut d'Investigacions Biomèdiques August Pi I Sunyer. "It's not surprising that scientists abroad are not keen to come to Spain."

Xavier Bosch, Barcelona

\section{Japan sets rules for stem cell research}

In an attempt to spur stem cell research and regenerative medicine, the Japanese government is getting its bioethical ducks in a row. But lingering resistance to the controversial fields will probably set limits on the speed and scope of the research.

On 1 July, the health ministry's ethics committee voted unanimously to allow the use of stem cells from aborted fetuses in clinical research. A week earlier, the bioethics committee of the Council for Science and Technology Policy (CSTP), Japan's highest science decision-making body, agreed on a recommendation that would allow therapeutic cloning.

The decisions come at a time when many Japanese researchers are waiting for a clear sign of support from the government for the controversial research. But both recommendations, which are likely to become the country's official policies, have met with controversy outside the scientific community.

"Has there been significant debate about these decisions?" asks an editorial in the Mainichi Shimbun newspaper. In an interview with Nature Medicine, Susumu Shimazono, a religious studies professor at the University of Tokyo and a member of the CSTP committee, accused committee chair Taizo Yakushiji of rigging the vote by not informing some members that there would be a vote that day and by only making the draft available to certain members beforehand. Yakushiji says he showed his draft to certain members for feedback and that he made efforts to let all members know there would be a vote.

The CSTP committee agreed to permit therapeutic cloning by a ten-to-five vote, but provisions for a system to license researchers and approve projects could take a long time. Motoya Katsuki, director of the National Institute of Basic Biology, voted against the proposal and calls for a moratorium of two to three years while the committee finds "a scientific basis" for the guidelines.

The health ministry committee is also taking steps to limit controversy about fetal stem cell research. In the absence of coherent legislation, several groups have been conducting research "underground," says Tatsutoshi Nakahata, a developmental pediatrician at Kyoto University and chair of the committee. No laws are being broken, but "it is very important that this research is done out in the open and approved by a central review committee," he says.

To forestall criticism, the guidelines will probably limit researchers to using stem cells from a single fetus, grown in vitro, for each patient, says Hideyuki Okano, a neuroscientist at Keio University and a member of the health ministry committee. In contrast, Parkinson disease researchers in other countries transplant stem cells from the brains of up to ten fetuses for each patient.

The health ministry committee expects to release its guidelines by October after reviewing procedures for informed consent and other ethical concerns.

David Cyranoski, Tokyo 